\title{
När förpackade idéer möter organisatoriska villkor
}

\author{
LINA PONNERT \& KERSTIN SVENSSON
}

\begin{abstract}
För att leva upp till kravet på en evidensbaserad praktik använder organisationer alltmer manualbaserade program. I den här artikeln analyseras och diskuteras spridningen och återinbäddningen av ett sådant program ur ett organisationsteoretiskt perspektiv med fält, program och personal ifokus.
\end{abstract}

\section{Introduktion}

I dagens sociala arbete finns ett tydligt inflytande från idéer om att interventioner i socialt arbete bör vara strukturerade, manualbaserade och utformade som "program". Programtanken kan kopplas samman med att det under det senaste decenniet har ställts krav på evidens inom socialt arbete (Bohlin och Sager 2011). Begreppet "evidens" infördes som idé i det medicinska fältet i början av 1990-talet och har därefter spridits till andra fält, och dess innebörd har omformulerats efter hand (Hult 2006). Bergmark och Lundström

Lina Ponnert, Universitetslektor, Socialhögskolan, Lunds universitet.

Kerstin Svensson, Professor, Socialhögskolan Lunds universitet.
(2011) beskriver hur det utformats två olika modeller för evidensbaserad praktik. Den ena handlar om att de som utför arbetet själva är "upplysta praktiker" som aktivt kombinerar sina kliniska frågeställningar med en kritisk värdering av bästa tillgängliga vetenskap. Den andra är en "uppifrånoch-ned-strategi" där riktlinjer skapas för arbetet baserat på sammanställda vetenskapliga studier av interventioner som visat sig vara effektiva.

I den generella diskussionen om vad evidensbaserad praktik i socialt arbete innebär har den senare modellen blivit ledande. I en sådan modell är de interventioner som utförs förpackade $i$ form av program som genomförs med stöd av manualer, vilket underlättar genomförandet av vetenskapliga studier och utvärdering. Programförpackningens starka 
ställning har bidragit till att allt fler program överförs mellan olika sammanhang. Bergmark och Lundström (2011) menar att det största problemet med evidensbaserade program är att de får mycket svårt att leverera vad som lovas, vilket riskerar att skapa mer besvikelse än professionell klarhet. Syftet med denna artikel är dels att fördjupa förståelsen för spridningen av manualbaserade program inom det sociala arbetets fält, dels att belysa och analysera hur det går till när ett sådant program får fäste och implementeras inom en organisation. Vilka faktorer och aktörer bidrar till att ett program sprids, hålls vid liv eller förkastas?

\section{Implementering, översättning och diffusion}

Vår utgångspunkt är att manualbaserade program kan betraktas som en uppsättning idéer som har materialiserats och förpackats i en standardiserad form, vilket möjliggör förflyttning mellan olika organisationer. Nyinstitutionell teori utgår från att organisationer har en tendens att härma varandra för att uppnå legitimitet och hantera den osäkerhet som mångfalden av val innebär (DiMaggio \& Powell 1983, Czarniawska \& Sevón 2005). Inom ett fält tenderar idéer som betraktas som framgångsrika att spridas mellan organisationer (Czarniawska \& Joerges 1996, Sahlin-Andersson 1996). Idéerna som sprids är sammansatta föreställningar som kan materialiseras som objekt eller handlingar, t.ex. så att de kan kallas för program och materialiseringen kan ske genom att pro- grammet standardiseras och formas ur en specificerande manual. Den process som sker när ett manualbaserat program införlivas i flera organisationer kan förstås som idéspridning, ett begrepp som relaterar till processen där idéer transporteras i tid och rum (Czarniawska \& Joerges 1996). Även om den är manualbaserad och paketeras, påverkas och förändras idén av den organisation som införlivar den, samtidigt som organisationen också påverkas (Czarniawska \& Joerges 1996, Erlingsdóttir 1999, Erlingsdóttir \& Lindgren 2005). Det finns därför anledning att se idéer som rörliga fenomen som förändras allt eftersom de landar i nya sammanhang (Czarniawska \& Joerges 1996). I denna process är kommunikativa handlingar centrala och fungerar som ett sätt att bära och omformulera idéer mellan sammanhang (Sahlin-Andersson 1996). Med ett idéperspektiv blir det organisationerna och översättningen av idéerna i det nya sammanhanget som blir centrala att studera (Johansson 2002).

Denna översättningsprocess, menar vi, kan studeras genom att fokusera på implementeringen av nya handlingsmönster, t.ex. i form av specifika interventioner, i en organisation. Implementeringsprocesser betraktas annars ofta som ett stegvist och rationellt skeende. Gustle (2007) menar att implementeringsforskning ofta beskriver hur processen bör gå till och delar in den i olika faser där det inom varje fas finns olika steg som behöver tas. Guldbrandsson (2007) har visat på likheterna i dessa beskrivningar och ställt samman förekommande checklistor. Alexandersson (2006) påtalar kritiskt att implementeringsforskningen är full av triviala checklistor, men 
att det sällan förekommer någon fördjupad analys. Svårigheter med implementering tolkas ofta som bristande kommunikation mellan forskning och praktik (Johansson 2010). Att studera implementering ur det perspektivet innebär att man ser idén som implementeras som ett objekt, inte som en medaktör i processen.

Studier om policyimplementering med utgångspunkt i företagsekonomi har dock i större utsträckning använt idéperspektivet (se t.ex. Erlingsdóttir 1999, Lavén 2008). Ett sådant perspektiv möjliggör att betrakta implementeringen som en process där även idén i sig har betydelse för det som sker. Latour (1998) ser idéer som förflyttas mellan sammanhang som artefakter och menar att även dessa bör betraktas som aktörer som påverkar processen. För att förstå processen måste därför programmet i sig betraktas som en medaktör, annars förlorar man en dimension i förståelse.

I stället för att studera implementeringens faser vill vi därför här använda idéperspektivet och begreppen översättning och diffusion för att förstå processen. Latour (1998) har visat på skillnaden mellan diffusion och översättning genom att tala om energiladdning. Diffusion beskriver han som en spridning i tid och rum, där en kraft sätter igång rörelsen och skapar energi, men där också en tröghet inverkar genom att spridningen saktas ned och omvandlas när den kommer in i nya sammanhang. I diffusionsmodellen betraktas det fenomen som sprids som oföränderligt och spridningen antas kunna ske utan att något arbete utförs av mänskliga aktörer. Översättningsperspektivet är istället kon- kret kopplat till människors handlande, var och en av de människor som kommer i kontakt med en idé är del i att sprida den vidare, eller att bromsa upp spridningen. Medan diffusionsmodellen utgår från en initial energi innebär översättningsmodellen att alla som medverkar också ger eller tar energi från idén och får den att öka eller förlora i värde. Var och en som medverkar gör också idén till sin egen och på så sätt förändras idén i kontakten med nya sammanhang och aktörer. I processen förhandlas idén till att passa i princip vilka problem som helst, förutsatt att det finns en god vilja och kreativitet hos inblandade aktörer (Czarniawska \& Joerges 1996). Latour (1998) menar därför att vi behöver studera samspelet mellan institutionerna, individerna och artefakterna för att förstå processer och skeenden. Han beskriver att idéer och föreställningar kan sägas vara förpackade i "svarta lådor", där varje låda innehåller en uppsättning uppfattningar om ett fenomen som tas för givet. Dessa lådor staplas på varandra och konstruerar därigenom uppfattningen om tingens ordning (Latour 1998). Czarniawska (2005) talar om att en idé urbäddas i översättningsprocessen när den tas från sitt ursprungliga sammanhang och återinbäddas och fylls åter med nytt innehåll när den kommer in i ett annat. Implementering kan därför ses som en form av återinbäddning, då programmet antar sin utformning i sitt nya sammanhang. I denna artikel studerar vi återinbäddningen av ett program i en organisation och packar upp de "svarta lådor" med föreställningar som medverkar i återinbäddningsprocessen. Vi betraktar organisationen, programmet och 
personalen som centrala aktörer i denna process.

\section{Material och empirisk utgångspunkt}

För att studera återinbäddning måste man ha ett konkret exempel att fördjupa sig i. Det program som vi här tar som exempel är Kometprogrammet och vi studerar processen när det skall föras in i verksamheten vid särskilda ungdomshem inom Statens Institutionsstyrelse (SiS). Vårt empiriska material utgörs av material om Kometprogrammets ursprung och utformning samt intervjuer med de personer som hade i uppdrag att genomföra och delta i utbildning och implementering av programmet. Materialet består av intervjuer med de tre personer som utbildade och handledde personal som skulle arbeta med programmet, enkätsvar från samtliga 17 personer som utbildades 2007-08, gruppintervjuer med personal vid tre ungdomshem samt texter om programmet och implementeringen. Därutöver har vi också haft många samtal med ansvariga inom SiS, med personer som utvecklar Kometprogrammet och intervjuat berörda ungdomar och föräldrar, dessa senare källor används dock inte explicit i denna artikel. Allt material samlades in med syfte att förstå de involverades syn på implementeringen av detta program vid de särskilda ungdomshemmen. Således handlade intervjuer, fokusgrupper och enkät om de berördas uppfattningar om Kometprogrammet och dess implementering. Empirin i sin helhet har tidigare redovisats i en rapport (Ponnert och Svensson 2008).

\section{Komet somförpackad idé}

Komet är ett manualbaserat föräldraträningsprogram som började utvecklas hösten 2002 vid Stockholms stad dåvarande FOU-enhet och som sedan vidareutvecklas av Preventionscentrum Stockholm (Precens). Det är de som äger programmet och som ansvarar för dess utformning. Det innebär att det är Precens som har samlat idéerna, paketerat dem i programform, upprättat en manual och angivit den standardiserade form som skall efterföljas. En standard omfattar såväl uttalade direktiv som mer implicita normer (Johansson 2002). Detta innebär att när en eller flera idéer förpackas i programform, för manualen de implicita normerna vidare och anger också ett uttalat mönster för handlingar.

Komet står för KOmmunikationsMETod och är baserat på kognitiv beteendeterapi. En utgångspunkt i programmet är att barn påverkas av föräldrars beteende och programmets syfte är att lära föräldrarna vikten av social samvaro med sitt barn, att kommunicera tydligare och att fokusera på att ge barnet beröm. Programmet bygger på metoder med sin bas i inlärningsteori och praktisk träning och har influerats av de program som utvecklades i USA på 1970talet, så kallade "Parent Management Training”, PMT-program (Kazdin 2005).

Kometprogrammet är således uppbyggt $\mathrm{i}$ Sverige, men utifrån idéer hämtade framför allt från USA och inspirerat av amerikanska PMT-program. Den standardiserade form det givits består i en serie sammankomster utifrån definierade teman. Den ursprungliga versionen av Komet (FöräldraKomet) vände sig till föräldrar med barn mellan 
3 och 11 år där en grupp föräldrar träffar gruppledare vid elva tillfällen och diskuterar specifika teman utifrån vardagliga situationer som bl.a. gestaltas i rollspel. Mellan träffarna får föräldrarna hemuppgifter att praktisera i samspelet med sitt/sina barn och följande möte inleds med en återkoppling till dessa hemuppgifter. Senare har programmet kommit att varieras och tilllämpas i olika sammanhang och för nya målgrupper: SkolKomet (som vänder sig till skolpersonal) Förstärkt Komet (som kombinerar gruppträffar med individuella träffar för familjer med hög social belastning). Den fjärde formen av Kometprogrammet är UngdomsKomet som riktar sig till föräldrar med ungdomar i åldern 12 till 18 år och är den variant av Komet som nu används på vissa särskilda ungdomshem.

\section{Vad hände? En kronologi}

Processen som här studeras sker i en tid då "evidens" och forskningsstöd för arbetet betonas. Det är något av grundförutsättningarna både för vad som kom att ske och hur vi kan förstå det. Forskning om ungdomsvård visade tidigt att möjligheterna att uppnå önskade resultat ökar om man involverar föräldrar och under 1990talet ökade arbetet med anhöriga (Kesthely 1999, Bangura Arvidsson och Åkerström 2000). På 2000-talet kom insatser i allt högre utsträckning att ta formen av program, inte minst sedan Tore Andreassen (2003) presenterat en forskningsöversikt om insatser på ungdomshem där metoder baserade på kognitiv beteendeterapi och social inlärningsteori lyftes fram som posi- tiva ur behandlingssynpunkt. Andreassen påtalade också behovet av att ha fler fokus $\mathrm{i}$ insatserna. Med det som grund inleddes 2005 ett nytt sätt att arbeta på flera särskilda ungdomshem, MultifunC, som kombinerade olika strukturerade insatser och knöts nära till vetenskaplig uppföljning och utvärdering (Statens Institutionsstyrelse 2011). I MultifunC ingick flera programbaserade insatser men man saknade ett program för arbetet med föräldrar. PMTprogram uppvisade generellt goda resultat, så man började söka efter ett sådant som kunde användas inom MultifunC. Kometprogrammet var utvecklat i Sverige och det fanns svenska manualer utarbetade. Det hade dessutom gott rykte, det var vetenskapligt förankrat och utvärderat för yngre barn (Kling m.fl. 2006). Programmet hade dessutom sin bas i kognitiv beteendeterapi och bedrevs i programform. I kontakter mellan centrala aktörer inom Statens Institutionsstyrelse och Precens kom man 2005 fram till en modell där SiS skulle involveras i utvecklingen av UngdomsKomet och programmet skulle användas inom SiS. En person anställdes inom SiS för att medverka i utvecklingen av programmet och man gjorde muntliga avtal för hur det hela skulle organiseras. När programmet presenterades för dem som arbetade med familjearbete kom det som en efterlängtad lösning. En representant för personalen beskrev det som:

Jag kände bara YES, det här är jättebra. Ett konkret program, inte speciellt svårt, utan det här är avgränsat och det kan ge föräldrarna väldigt mycket, så det var det (Handledare 2). 
Hösten 2006 startade en utbildning i Kometprogrammet där personal från SiS deltog. Vid det tillfället fanns dock bara Komet riktat till föräldrar med barn i åldern 3-11 år, men under tiden som gruppledare utbildades pågick arbetet med att utveckla en Komet-manual riktad till för tonårsföräldrar, där personal från SiS var involverade.

Och under den tiden så hade vi ju då diskussioner med - - vad är det för skillnad mellan barn 3-11 och 11-18 och så hade vi några sittningar och så började de då skissa på en förändrad manual (Handledare 1).

Eftersom det var ett färdigpaketerat program behövde de som skulle arbeta med det vara inskolade i det, de skulle kunna följa programmet helt enligt manualen, men manualen var vid det tillfället inte anpassad till SiS målgrupp. Ambitionen var att successivt införa Komet på alla särskilda ungdomshem, med början på de som arbetade med MulitfunC i västra och södra regionen.

En central, nationell, styrgrupp med representanter från SiS huvudkontor, från ungdomshem med MultifunC och från företrädare för programmet bildades. Gruppen fann aldrig någon stabilitet, redan under första året började personer bytas ut, någon gick på föräldraledighet, flera fick andra anställningar eller andra uppdrag inom organisationen. Detta gällde såväl dem som var med i styrgruppen som dem som utbildats i programmet. I berättelserna om implementeringen återkommer beskrivningar av att utbildade personer som varit involverade i Komet slutat sitt arbete och lämnat en tomrum efter sig. Ett exempel är beskrivningen av när en av de få första utbildade lämnar sitt arbete och därmed faller möjligheten att driva programmet på det ungdomshemmet eftersom ingen kan ta över uppgiften. "Sen var det kanske synd att hon som gick då, - - - hon var gravid då också, så att det ... Ja, men det kan man inte hjälpa, sånt händer" (Handledare 1).

Styrgruppen som skulle driva implementeringen var löst sammansatt. Det fanns en programansvarig som hade tid avsatt för att särskilt följa och driva på utvecklingen av programmet, men denna funktion kom att innehas av flera olika personer över kort tid. Till programmet var också huvudkontorets metodutvecklare och forskningsledare för ungdomsvård kopplade. Även dessa funktioner kom att bemannas med olika personer. Under implementeringsfasen och de första årens arbete med Komet blev därmed hela kärnan i gruppen av människor kring programmets implementering utbytt. Trots det hade bl.a. utbildningarna gjort att programmet levde vidare så länge det fanns utbildad personal.

Problemen med själva programmet var stora eftersom förutsättningarna var så annorlunda på ungdomshemmen jämfört med i öppenvård där programmet utarbetats, inte minst eftersom barn och föräldrar lever åtskilda.

Så det, är som jag ser det, de två stora problemen, det är kort om tid och det är svårt att få ihop grupperna. Det andra är att föräldrarna har svårt att få träffa eleverna. Så därför är de nästan, de måste ha varit här ett bra tag och komma upp på en nivå där de får åka hem varje helg, för att man skall få praktisera det här(Gruppintervju 3). 
Arbetet på ungdomshemmen har också förskjutits från att enbart fokusera på den unge till familjearbete. Införandet av Komet innebar att föräldrarna blev huvudfokus för interventionen. UngdomsKomet var vid denna tid ett nytt program även inom öppenvården, och som sådant fortfarande under revidering. Således pågick utbildning och revidering av programmet parallellt och det fanns bland SiS personal en utbredd uppfattning om att det var möjligt att förändra och påverka programmet så att det blev specifikt för SiS förutsättningar.

I september 2008 var programmet reviderat. Det var inte ett specifikt program anpassat till förutsättningarna på ungdomshemmen och inte heller vetenskapligt utvärderat, men det hade utformats för att kunna fungera även inom SiS. Samtidigt avstannade utvecklingen inom SiS. Metodutvecklaren deltog i arbetet med utveckling av programmets innehåll, en del kontakter togs och utbildningar av grupphandledare fortsatte. Omsättningen av programmet till praktisk handling hade däremot avstannat, Kometprogrammet bedrevs i väldigt liten skala och med tveksam programtrohet. Styrgruppen för Kometprogrammet lades ned i slutet av 2009 när ytterligare en av personerna på de centrala funktionerna slutade sin anställning.

Kometprogrammet bedrivs fortfarande inom SiS och har spridits till ett tiotal ungdomshem, framför allt i södra och västra Sverige. Den manual som nu används är UngdomsKomet från oktober 2009. Trots att det är i strid med programidén och manualen säger riktlinjerna inom $\mathrm{SiS}$ att man inom organisationen får bedriva Kometutbildning individuellt med föräldrar, men med förbehåll att man inte kan bli certifierad gruppledare i Komet utan att bedriva gruppverksamhet. Man arbetar också med mindre grupper av föräldrar och kan ha flera olika utbildningsteman vid ett och samma tillfälle, så att föräldragrupperna träffas längre stunder men vid färre tillfällen, för att minska antalet resor för föräldrar. Det finns inte längre någon styrgrupp och ingen särskild funktion som projektansvarig för enbart Komet. Det finns inte heller längre någon uttalad spridningsstrategi inom SiS.

\section{Hur kan detta förstås?}

Idén om Kometprogrammet lanseras starkt, tillförs resurser, ges näring genom utbildning och förlorar ändå snabbt energi varmed spridningen avtar. Vi ska nu försöka förstå de processer som sker när en idé förs in i ett nytt sammanhang. Latours (1998) sätt att se även strukturer och artefakter som medaktörer kan hjälpa oss att förstå. Vad är det då för aktörer vi kan se i detta sammanhang? Vi har definierat ett organisatoriskt fält där ett antal idéer som materialiserats och paketerats som program har stort inflytande. Vi har också definierat en organisation som behöver hitta former för att bedriva sitt arbete och dessa organisationer upprätthålls av individer med ambitioner att göra bästa möjliga arbete. Vi ser därför processen ur tre perspektiv: det organisatoriska fältets, idéns och personalens. 


\section{Det organisatoriska fältets perspektiv}

Ett sätt att förstå varför Komet infördes på särskilda ungdomshem kan vara att titta närmare på det organisatoriska fält som särskilda ungdomshem verkar i. Ett organisatoriskt fält innebär ett område där flera olika organisationer, med olika resurser, delar på ansvaret för liknande uppgifter (DiMaggio \& Powell 1983). Särskilda ungdomshem verkar, tillsammans med t.ex. kommunernas socialtjänst och privat eller offentligt styrda behandlingshem i samma organisatoriska fält, där de har ett gemensamt ansvar för att rehabilitera ungdomar med sociala problem. En bärande idé inom detta fält är att arbetet skall bygga på en evidensbaserad praktik, och för att kunna hävda sin legitimitet inom fältet behöver organisationer kunna argumentera för att man arbetar evidensbaserat. Institutionsvården för unga är ett av de områden som fått starkast kritik för att sakna kunskapsbas av arbetet, då "miljöterapi" länge uppgavs vara den dominerande "metoden" på institutionerna (Sallnäs 2006). Institutionsvården befann sig därmed i en legitimitetskris (jfr Hasenfeld 2010). En av de intervjuade handledarna beskriver det:

Det är ju en sådan konkurrenssituation att man måste jobba, man måste vara på framkanten för att se till att man jobbar evidensbaserat, så att det är bra innehåll (Handledare 2).

I dagens sociala barnavård betonas också idén om att kommunerna bör satsa mer på öppenvård (Forkby 2005, Ahlgren 2007).
Satsningen på öppenvårdsinsatser i kommunerna har troligtvis påverkat innehållet och ungdomshemmens arbete och uppdrag, då det krävs en annan flexibilitet för att möta upp nya beställningar från kommunerna då vårdtiderna på institutionerna blivit kortare (Socialstyrelsen 2004, s. 32).

Ett tag så fanns det liksom ingen hemmavård, eftervård på hemmaplan. Och då fanns det här. Och sen nu då så erbjuder man eftervård här. Men nu har kommunerna då byggt upp verksamhet $i$ kommunen så då vill de köra sitt. Så att det svänger ju hela tiden (Gruppintervju 2).

Samtidigt finns i fältet en idé om behov av mer generellt riktat föräldrastöd. Stöd åt föräldrar och en nationell satsning på föräldrautbildningar ingick i de åtgärder för en ny folkhälsopolitik som regeringen avsatte medel till under perioden 20082010 (prop. 2007/08:110, SOU 2008:131). Denna idé kan betraktas som ett resultat av flera samverkande faktorer, där kommunernas sökande efter preventiva metoder som lämpar sig i öppenvård är en bidragande faktor (Socialstyrelsen 2006). Anpassningen till FN:s barnkonvention och en ny syn på barn som subjekt, har också medfört tankar om hur ett gott föräldraskap bör se ut som stödjer iden med generella föräldraprogram (SOU 2008:131, s. 18).

Föräldraprogram är därmed en idé som kan kopplas till andra förhärskande idéer inom fältet. Med den kopplingen har idén lättare att få fäste (Czarniawska \& Joerges 1996, Erlingsdóttir 1999, s. 33). Att ett manualbaserat program riktat mot föräldrar förs in i en verksamhet inom detta 
organisatoriska fält kan därför te sig helt logiskt. Förväntningarna inom fältet betonar program och stärkande av föräldrarollen samtidigt som den enskilda organisationen behöver legitimera just sin existens genom att visa på kvalitet. Ett program som i annat sammanhang har visat goda forskningsresultat och som knyts till vidare utveckling och utvärdering ligger därför helt i linje med fältets förväntningar.

\section{Programmets perspektiv}

Den idé som i vårt exempel urbäddas från sitt sammanhang, och skulle återinbäddas i ett nytt sammanhang, var ett program som visat goda resultat när det bedrevs i öppenvård för föräldrar till barn 3-11 år. Programmet fanns nu i en form för föräldrar till äldre barn, ungdomar. Inte bara formen, utan även sammanhanget var nytt och i det sammanhanget fanns inte några resultat att utgå ifrån. En av de centrala skillnaderna mellan programmet i sin ursprungliga kontext och den nya är att det handlar om prevention på vitt skilda nivåer.

I utvecklingen och spridningen av Komet till nya målgrupper och sammanhang har det skett en glidning på preventionsskalan, från en universell prevention till föräldrar med små barn, till en selektiv målgrupp i öppenvård (ungdomar i riskzon) för att slutligen landa i SiS, där man arbetar man med redan etablerade riskgrupper, dvs. indikerad prevention. Denna glidning i preventionsskalan ledde till problem att bedriva

1 De olika preventionsnivåerna beskrivs t.ex. i Ferrer-Wreder m.fl. 2005, SBU 2010. programmet inom de särskilda ungdomshemmen. Problem som personal var mycket medvetna om. I en gruppintervju säger de t.ex.:

Jag tror att, det är ju som sagt en mängd svårigheter då, - - - , jag menar, det här är ju ett program som är framtaget för föräldrar, eller för familjer, som är ganska så funktionella ändä(Gruppintervju 2).

För att lösa den konflikten strävar man inom organisationen mot att programmet skall anpassas till förutsättningarna i organisationen.

Det är inte bara målgruppen och preventionsnivån som är problematisk. Även programmets form vållar bekymmer. I sin ursprungsform bygger programmet på kontinuerliga gruppträffar med möjlighet till träning i mötet med barnet eller ungdomen mellan träffarna. De familjer där ungdomar placeras på särskilda ungdomshem har ofta sammansatta sociala problem, vilket kan göra det svårt för föräldrar att delta i gruppverksamhet med regelbundenhet. Detta har också lyfts fram som ett generellt problem när föräldraträningsprogram implementeras i öppenvården (Mulford \& Redding 2008). Ytterligare ett problem är att föräldrar ofta bor långt ifrån ungdomshemmet där den unge är placerad, vilket kräver föräldrar som vill och har möjlighet att resa för att delta i programmet. Avståndet mellan barn och föräldrar i vardagen gör det också svårt att få till stånd tillräckligt med naturliga möten mellan föräldrar och barn mellan gruppträffarna. Dessa praktiska problem har gjort det svårt att få stabila och fungerande grupper och Komet inom SiS har ofta 
kommit att bedrivas med enskilda föräldrapar eller väldigt små grupper, vilket var en farhåga personalen tidigt kunde se.

Sen är ju erfarenheten av - - det här som från början har varit gruppbaserat. Det blir ju individuellt här och jag kan tänka mig att det här kommer också att bli, finnas ett behov av att använda det individuellt. Alltså intentionerna kanske är i grupp men $i$ praktiken tror jag bara det kommer bli enskilda föräldrar (Gruppintervju 3).

Implementeringsproblemen förstås ofta i termer av att det är programmet som är fel, ibland att organisationen inte tagit till sig programmet på rätt sätt. De föreslagna lösningarna blir ändå inledningsvis att det är programmet som bör anpassas till villkoren inom SiS. En handledare säger:

För SiS del så är det ju att ... programvaran är inte anpassad till institutionsvairden, utan det är ju ett öppenvårdsprogram. Och det har ju varit väldigt tydligt att det har ju inte varit förankrat i organisationen. Det har funnits en tanke om att det här är bra för SiS och att det här kan var ett bra innehåll som även våra föräldrar kan ta del utav. - - Så det är ju den stora nackdelen, nackdelen är ju naturligtvis också att våra barn och ungdomar, de bor här. Och programmet är ju utvecklat för att det är föräldrarna som skall träna och göra saker tillsammans med sina barn så att de har ju inte lika stora möjligheter kanske. Det måste se ut på ett annorlunda sätt (Handledare 2).

Begreppet "programtrohet" är centralt i tanken om evidensbaserat arbete och därför också en given del i utbildningen för dem som skall arbeta med programmet.

När då sammanhang och idé inte stämmer överens strävar sammanhanget efter att paketera om idén så att den skall fungera. En handledare beskriver det komplicerade arbetet med att få ihop grupper och upprätthålla programtrohet:

Det är därför som jag har haft det som en käpphäst att eftersträva grupper, trots att det har varit jäkligt jobbigt att få till. För risken är, som jag säger. Har man inte så att programmet sitter ordentligt, så är risken stor att du gör något helt annat än vad det är tänkt att du skall göra. Och där kan liksom gruppformen bli en press på dig själv att följa manualen mera strikt (Handledare 1).

I enkäten där personal under utbildning i Kometprogrammet får återge sin syn på programmet och implementeringen återkommer uttalanden som visar att man både är mån om programtroheten och ser problem med det program de utbildas i. Ibland argumenterar man för att målgruppen behöver något annat och skriver t.ex.:

Viktigt att anpassa Komet till SiS målgrupp för att dessa familjer ska slippa känna sig 'svaira', 'konstiga', 'dåliga' etc. Inte behöva känna sig som ett undantag som så ofta är fallet (Enkät 3).

Ibland handlar argumenten om att det är programmets trovärdighet som är i fara:

Absolut måste det skapas en SiS-Komet för den manual som finns nu är alldeles för lam jämfört med de situationer våra föräldrar 
befinner sig $i$ med sina ungdomar som har LVU, drogproblem, alkohol, självskadebeteenden, rymningar osv. (Enkät 2).

Ett tredje sätt att argumentera om programmet och programtrohet är att uttrycka oro för hur organisationen kommer att hantera det, som när en enkätrespondent skriver om att förhoppningarna är "att få klara direktiv från $\mathrm{SiS}$ och att alla SiS-Komet utbildningar kommer att se ungefär lika ut" (Enkät 15).

Kometprogrammet i sig är alltså en stark aktör i sammanhanget, programtroheten är viktig, programmet som "varumärke" och artefakt är viktigt. Men ändå strävar man inom organisationen efter att göra det till något annat än vad det är i sin befintliga idé och förpackning. Erlingsdóttir och Lindberg (2005) har visat på hur idéer som införlivas $i$ en organisation kan vara "second-hand and not a good fit", "ready-towear" eller "costume-made". Programmet var i detta sammanhang klart att använda, men det skräddarsydda program man hoppades på blev aldrig verklighet och sammanhanget passar egentligen dåligt. I en gruppintervju uttrycker man det mycket tydligt: "Men om man skulle titta helt optimalt då, så skulle det ju egentligen inte lämpa sig för den här typen av verksamhet" (Gruppintervju 1). Organisationens lösning blir i den situationen att försöka finna lösningar till att både bevara programtrohet och ta till sig Kometprogrammet.

\section{Personalens perspektiv}

För att en idé ska kunna omsättas i ett nytt organisatoriskt sammanhang krävs en förankring i det organisatoriska fält där en idé diskuteras och framställs som normativt riktig. Vidare krävs att idén landar i organisationen vid en tidpunkt när en förändring är genomförbar och lämplig, för att den också skall genomföras i handling (Johansson 2002). På många av de särskilda ungdomshem där Komet introducerades, och där Komet fortfarande används, fanns redan en kunskap om att arbeta med föräldrastöd och med manualbaserade program, som underlättade denna handling. I genomförandet av Komet har det därmed också funnits starka idébärare inom SiS med ett starkt engagemang för familjeperspektiv och tilltro till programmet som drivit på införandet och bevarandet av Komet på vissa särskilda ungdomshem.

Enligt Latour (1998) innebär översättning att alla handlande aktörer kan påverka olika riktningar och således har makt över processen. Det innebär att de har inflytande över vart och hur programmet sprids och får fäste. I en intervju diskuteras vilken personal som kommer att få bli Kometutbildad.

Utan det kommer att bli så att säga, som det alltid är, de som visar framfötterna och är intresserade. De har ju möjligheten att kanske fä först. Och då blir ju bekymret det här att om det inte är så att säga förankrat $i$ den stora organisationen, eller institutionen, så kommer de ju att sen, när de har fätt utbildningen, flytta till något annat ställe där man blir mer uppskattad och där det tas tillvara på(Handledare 1).

Personal söker sig till utbildningen för att 
antingen kunna få en specifik funktion i organisationen, som den person under utbildning skriver: "Utbildningen var en förutsättning för att jag skulle kunna ingå $i$ familjeteamet" (Enkät 6), eller för att skapa bättre förutsättningar för den funktion man redan har: "Att jag som gruppledare ska bli mer säker i min roll" (Enkät 16).

Utbildningen ger därmed personal energi och näring i deras arbete. Förväntningarna på programmet är att det både skall ge intressantare arbetsuppgifter och bättre utfall av arbetet. När programmet väl finns i organisationen och personalen är utbildad, då blir det personalens intresse som styr det som sker, inte nödvändigtvis målgruppens behov. En handledare säger: "Nu är de här gruppledarna utbildade och klara. För att de skall bibehålla sin kompetens och utvecklas, så måste vi ju ha grupper" (Handledare 1).

Utbildad personal bidrar till att upprätthålla programmet, trots de problem som uppmärksammats med genomförandet. I förra avsnittet visade vi exempel på hur man strävar efter att förändra programmet när implementeringen inte löper friktionsfritt, men det finns också många kommentarer om bristande stöd inom organisationen. I enkäterna till personal under utbildning finns återkommande utsagor om farhågor som "Att chefer o dyl. inte vet vad det handlar om och inte ser vikten av att tid och kompetens krävs för att kunna göra ett bra arbete" (Enkät 3). "Ointresse från institutionsledningen och att det rinner ut i sanden" (Enkät 11) och "Att det går för långsamt i planeringen" (Enkät 13). Handledarna beskriver också farhågor med att organisationen inte kommer att kunna stödja det arbete som behövs för att hålla igång programmet och ge personalen tillräckligt med utrymme.

Kometprogrammet blir alltså en energigivare för personalen, som därmed håller programmet levande. Men vad programmet innebär och hur det omsätts i praktiken kan man inte riktigt veta. Personalens energi kan inte bara användas till att implementera programmet, utan också till att omvandla det till något annat. Sannolikheten för en sådan omvandling ter sig tämligen stor när entusiasm har skapats kring ett program där det finns påtagliga komplikationer för implementeringen.

\section{Aktörernas samspel}

I förra avsnittet separerades de tre olika perspektiven organisatoriskt fält, program och personal för att tydliggöra de krafter och aktörer som kan verka för att ett program förs in i en verksamhet. Vi skall nu lägga samman perspektiven för att fördjupa förståelsen av vad det är som sker när ett program implementeras och förväntningarna möter hinder. Den första fråga man måste ställa sig är: Varför valde man överhuvudtaget att ta in Kometprogrammet på de särskilda ungdomshemmen?

Kometprogrammet var rätt på många sätt. Det svarade upp mot de institutionaliserade uppfattningar som rådde på det organisatoriska fältet. Czarniawska och Joerges (1996) skiljer mellan institution, förhärskande idéer och mode för att utröna huruvida en idé får långvarigt eller tidsbegränsat genomslag. Organisationers trendkänslighet och benägenhet att införliva nya 
och "trendiga" metoder, kan förstås utifrån att moden bringar ordning och enhetlighet i ett annars osäkert fält (ibid. s. 35). Moden som knyter an till förhärskande idéer i fältet ökar också sin möjlighet att få fäste och utvecklas till institutionaliserade idéer. Med den distinktionen måste man betrakta idéerna om prevention, föräldraarbete och evidensbaserat arbete som institutionaliserade. De var grundligt förankrade i fältet och de överensstämde mycket väl med den förpackning och det innehåll som Komet erbjuder. Kometprogrammet har inte bara tagits in inom $\mathrm{SiS}$, utan finns även inom en stor del av landets kommuner och är ett erkänt program. När det förs in i organisationen betraktas det därmed som lösningen, som "den rätta metoden" och som ett sätt att leva upp till omvärldens förväntningar och krav. I en gruppintervju beskrivs entusiasmen såhär:

Personligen tycker jag att Komet är ett fantastiskt program. Om vi, hur vi, omsätter det $i$ verkligheten. Jag har stort intryck av Komet i Stockholm, där det lyckas. Här vi vet inte så mycket om Komet. Jag vet ingenting. En del vet jag, men vad gör de, träffar föräldrar, snackar, men om vadå? (Gruppintervju 3)

Komet konstrueras som en framgångshistoria inom öppenvården, och ungdomshemmen imiterar den rationalitet som programmet förknippas med (jfr SahlinAndersson 1996). Programmet blir vad Meyer och Rowan (1977) kallat för "en rationaliserad myt", en vedertagen uppfattning om en vandrande lösning. En sådan får snabb, men ogenomtänkt, spridningsef- fekt eftersom lösningen framställs vara god oavsett i vilket sammanhang den tillämpas. Czarniawska och Joerges (1996, s. 19) menar att ofta pågår redan en mängd handlingar inom en organisation som behöver en idé för att legitimeras. Om aktören/organisationen då påstår sig replikera handlingar som varit framgångsrika i andra sammanhang, så betraktas detta som acceptabelt, trots att villkoren och förutsättningarna kan skilja sig väsentligt från det ursprungliga sammanhanget (ibid.). I detta sammanhang fanns MultifunC som efterfrågade ett program för föräldrar, och av aktörerna nämns Komet tidigt tillsammans med legitima kodord som "evidensbaserat", "program", "föräldrastöd" och "manual" vilket ger både legitimitet och trygghet och personalen hoppas få verktyg för att lyckas i sitt arbete. Därmed tillförs ytterligare energi till översättningsprocessen när personal erbjuds och genomgår utbildningen, eftersom programmets ställning i organisationen då stärks och upprätthålls.

Samtidigt kvarstår de grundläggande problemen: programmet passar inte in $\mathrm{i}$ organisationen. Det saknas grundläggande förutsättningar som kontakt mellan barn och föräldrar för träning på momenten $\mathrm{i}$ programmet, målgruppens problem är mer komplexa än i det sammanhang programmet skapats, det går inte att hålla samman grupper av föräldrar och det är problematiskt att ordna personalens arbetsschema så att de kan bedriva programmet. Initialt ser aktörerna detta som hinder som skall övervinnas och den lösning som mest lyfts fram är att programmet borde "justeras". Samtidigt är programmet är en stark aktör i sig och vikten av programtrohet förankras väl både 
i organisationen och hos personalen. Det är alltså en kluven bild: $\AA$ ena sidan är programmet något av räddningen, å andra sidan är det faktiskt ett annat program man efterfrågar. Det finns något paradoxalt i personalens och organisationens förhållningssätt.

James D. Thompson (1971) har beskrivit detta som den "administrativa paradoxen" och syftar på att organisationer ofta söker flexibilitet och säkerhet samtidigt, vilket gör att de kan kritiseras samtidigt både för inkonsekvens och godtycklighet och för tröghet och regeltänkande. När ett program skall föras in i en organisation kan stabiliteten, som i vårt exempel, kopplas till programmets starka ställning som artefakt och medaktör. Programtrohet betonas och ger såväl legitimitet som stabilitet, regeltänkande och tröghet. Trots att de inledande förhoppningarna om en manual anpassad för SiS grusas, förblir programmet stabilt, istället är det personalens arbetssätt som kräver flexibilitet för att programmet ska kunna överleva inom SiS. En flexibilitet som strider mot idén om programtrohet. Detta sker t.ex. genom att föräldrar kan få möjlighet att ta igen missade grupptillfällen eller genom att enstaka utbildningstillfällen sker hemma hos föräldrar eller på annan ort. Flexibiliteten blir därmed beroende av personalens lösningar på hur de skall hantera regelverk och manual, vilket gör att metoden kan anpassas i återinbäddningen inom SiS utan att legitimiteten går förlorad. Energin för att fortsätta att bedriva Komet blir därmed alltmer beroende av enskilda och utbildade personer på särskilda ungdomshem. De olika aktörerna driver alltså processen olika och det är i samspelet och i dynamiken mellan dessa som praktiken skapas.
Tröghetens mekanismer i organisationer beror enligt Ahrne och Papakostas (2002) på en oförmåga att handla och en ovilja till förändring t.ex. på grund av lojalitet eller rädsla för försämringar. Genom att separera organisationens perspektiv från personalens kan vi här se att det är organisationen, dvs. verksamhetens struktur, och kravet på programtrohet som står för trögheten, medan personalen möter denna tröghet med flexibilitet. Människorna i organisationen vill åstadkomma förändring, men strukturen i organisationen omöjliggör den. Trögheten är, precis som Ahrne och Papakostas beskriver den, ett skydd för att bevara organisationen.

Komet blev ingen lösning, översättningen och spridningen begränsades och successivt laddades energin ur när problemen med det praktiska genomförandet återkom, när personer som burit idén lämnade sin funktion i organisationen och personalens roll som energigivare till översättningsprocessen tonades ned. Energin från programmet i sig avtog också när det stod klart att den utvecklade manualen för UngdomsKomet inte var det samma som den "SiS-Komet" som man hoppats på. Återinbäddningen av idén i detta nya sammanhang blev avsevärt mindre än förväntat. Numera erbjuds institutionerna kostnadsfri utbildning i Komet, men det finns inte längre någon central idé om spridning. Det är upp till varje institution att avgöra om organisationen ska bedriva Kometutbildning eller inte och det finns inte längre någon central styrgrupp som driver utvecklingsfrågor.

Det fanns en initial energi som förstärktes i organisationen och av personalen. 
Efterhand minskade energin och processen avstannade när den mänskliga kraften $i$ form av personalens entusiasm avtog till följd av tröghet i den organisatoriska strukturen och i programmet. Detta exempel visar att det ur ett organisatoriskt perspektiv ofta finns både förhoppningar och maktanspråk i att anpassa en idé till lokala förutsättningar, vilket strider mot programtanken som idé. Organisationen "tänker" via mänskliga aktörer ur ett översättningsperspektiv medan programtanken bygger på idén om diffusion. Att förstå de processerna kan bidra till att förstå svårigheterna med implementering.

\section{Diskussion}

Vi har i denna artikel visat ett exempel på en implementeringsprocess av ett program. Vi har använt Kometprogrammet inom Statens Institutionsstyrelse som exempel, men det finns all anledning att fundera över om detta på något sätt är en unik företeelse. Skulle det kunna hända samma sak i andra organisationer? Ja, med största sannolikhet. Det finns i och för sig specifika karakteristika inom just denna organisation, just detta program och hur de fungerar tillsammans. Men det finns all anledning att anta att liknande processer sker med andra program i andra organisationer i detta organisatoriska fält.

Många program bedrivs i hopp om att de skall bli "evidensbaserade", dvs. att kommande vetenskapliga studier skall visa att de leder till önskade resultat. Men resultaten låter sig dröja och det är inte alls ovanligt att studierna istället visar att program leder till oönskade resultat. Under tiden arbetar personal i många organisationer vidare med programbaserat arbete och låter sina förhoppningar ge energi åt implementeringen utan att man egentligen vet vart det leder. Ett exempel är t.ex. området förebyggande psykisk ohälsa, där det i Sverige idag över huvud taget inte utvärderats något program i kontrollerade studier och det alltså saknas styrkt effekt. Inte heller har något importerat utvärderat program som används i Sverige vetenskapligt stöd för att ha förebyggande effekt (SBU 2010). Den snabba spridningen av manualbaserade program inom svensk barn- och ungdomsvård bör därmed snarare förstås och förklaras organisationsteoretiskt än utifrån programmens praktiska och förväntade nytta. En analys av vilka bärande idéer en intervention vilar på skulle kunna vara ett stöd i beslutsprocessen innan organisationer beslutar sig för att implementera en intervention. Det är inte alls omöjligt att det kan finnas manualbaserade program som kan visa sig både fungera $i$ organisationer och ge önskade effekter, men det innebär inte nödvändigtvis att det är överförbart till andra sammanhang. Den entusiasm som personal kan känna inför möjligheten att finna förpackade lösningar på svåra uppgifter i sitt arbete ger energi till implementering, och är kanske rent av nödvändig för att förändring och implementering av nya metoder skall fungera. Energin och förväntningarna hos personal och de investeringar som görs $i$ form av utbildning, kan bidra till att förstå varför program kan leva vidare inom en organisation, trots stora praktiska problem, Denna energi kan också, som Bergmark och Lundström (2011) också påpekar, skapa 
besvikelse när t.ex. ett program inte uppfyller förväntningarna.

Interventioner som baseras på generella antaganden om "vad som fungerar" riskerar att på sikt bli mer resurskrävande än energigivande för såväl organisation och perso- nal. Kanske skulle den form av evidensbaserat arbete där arbetet bedrivs av "upplysta praktiker" vara mer energigivande än den linje som verkar dominera idag, som är baserat på riktlinjer för "det goda arbetet".

\section{Referenser}

Ahlgren, T. (2007). Ungdomsbehandling. Hemmaplanslösning som idé och praktik. Lic. avhandling. Rapportserie i socialt arbete. $\mathrm{Nr} 8$. Växjö: Växjö universitet.

Ahrne. G. \& Papakostas, A.(2002). Organisationer, samhälle och globalisering. Lund: Studentlitteratur.

Alexandersson, K. (2006). Vilja Kunna Förstå. Om implementering av systematisk dokumentation för verksamhetsutveckling $i$ socialtjänsten. Örebro Studies in Social Work 7. Örebro: Institutionen för beteende-, social- och rättevetenskap.

Andreassen, T. (2003). Institutionsbehandling av ungdomar. Vad säger forskningen? Stockholm: Gothia, Centrum för utvärdering av socialt arbete (CUS), Statens institutionsstyrelse (SiS).

Bangura Arvidsson, M. \& Åkerström, M. (2000). När anhöriga involveras. Personalens beskrivning av anhöriga på särskilda ungdomshem. Forskningsrapport nr 2, 2000. Stockholm: Statens institutionsstyrelse.

Bergmark, A.\& Lundström, T. (2011). Evidensbaserad praktik i svenskt socialt arbete. Om ett programs mottagande, förändring och möjligheter i en ny omgivning. I Bohlin, I. och Sager, M. (red.) Evidensens många ansikten. Evidensbaserad praktik i praktiken. Lund: Arkiv.

Bohlin, I. och Sager, M. (2011). Evidensens många ansikten. Evidensbaserad praktik i praktiken. Lund: Arkiv.

Czarniawska, B. (2005). En teori om organisering. Lund: Studentlitteratur.

Czarniawska, B. \& Joerges, B.(1996). Travels of ideas. I Czarniawska B. \& Sevón G. (red.)
Translating Organizational Change. Berlin: de Gruyter.

DiMaggio, P.J \& Powell, W.W. (1983). The Iron Cage Revisited. Institutional Isomorphism and Collective Rationality in the Organizational Fields. American Sociological Review, vol. 48 (April), ss. 147-160.

Erlingsdóttir G. (1999). Förförande idéer - kvalitetssäkring i hälso- och sjukvården. Lund: Ekonomihögskolan.

Erlingsdóttir G. \& Lindberg K. (2005). Isomorphism, Isopraxism, and Isonymism: Complementary or Competing Processes. I Czarniawska B.\& Sevón, G. (red.) Global ideas: How Ideas, Objects and Practices Travel in the Global Economy. Malmö: Liber \& Copenhagen Business School Press.

Ferrer-Wreder L., Stattin, H.,Lorente, C. C., Tubman, J. G., \& Adamson, L. (2005). Fram gångsrika preventionsprogram för barn och unga. En forskningsöversikt. Stockholm: Gothia/IMS/SiS.

Forkby, T. (2005). Ungdomsvård på hemmaplan. Idéerna, framväxten, praktiken. Göteborg: Göteborgs universitet, Institutionen för socialt arbete.

Guldbrandsson, K. (2007). Från nyhet till vardagsnytta. Om implementeringens mödosamma konst. Statens folkhälsoinstitut 2007:20. Stockholm: Statens folkhälsoinstitut.

Gustle, L.H.(2007). Implementering och korttidsuppföljning av Multisystemisk terapi. En svensk randomiserad multicenterstudie angående Multisystemisk terapi. Lund: Lunds universitet, Institutionen för psykologi. 
Hasenfeld, Y. (red.) (2010). Human services as complex organizations. 2. ed. Los Angeles: Sage.

Hult, E. (2006). Vetenskap i paketerad form. Framväxten av evidensbaserad medicin. I Levay, C. \& Waks, C. (red.) Strävan efter transparens. Granskning, styrning och organisering $i$ sjukvårdens nätverk. Stockholm: SNS Förlag.

Johansson, R. (2002). Nyinstitutionalismen inom organisationsanalysen. Lund: Studentlitteratur.

Johansson, S. (2010) Implementing evidence-based practices and programs in human services: lessons from research in public administration. European Journal of Social Work, vol. 13, nr 1, ss. 109-125.

Kazdin, A. E. (2005). Parent management training. Treatment of oppositional, aggressive, and antisocial behavior in children and adolescents. New York: University Press.

Kesthely, M. (1999). Med familjen för förändring. Institutionsbaserat familjearbete. Föräldraprojekt på särskilda ungdomshem och LVM-hem 1995-98. SiS följer upp och utvecklar 2/99. Stockholm: Statens institutionsstyrelse.

Kling Å., Sundell, K., Melin, L. \& Forster, M. (2006). Komet för föräldrar. En randomiserad effektutvärdering av ett föräldraprogram för barns beteendeproblem. FoU-rapport 2006:14 Stockholm: Stockholm Stad, Forsknings- och Utvecklingsenheten.

Latour, B. (1998). Artefaktens återkomst. Ett möte mellan organisationsteori och tingens sociologi. Stockholm: Nerenius \& Santérus Förlag.

Lavén, F. (2008). Organizing innovation. How policies are translated into practice. Göteborg: BAS Publishing.

Meyer, J. \& Rowan, B. (1977). Institutionalized Organizations: Formal structure as Myth and Ceremony. American Journal of Sociology, vol. 83, nr 2, ss. 340-363.

Mulford, D. C. \& Redding, E. R. (2008). Training the Parents of Juvenile Offenders: State of the Art and Recommendations for Service Delivery. Journal of Child and Family Studies, vol. 17, nr 5, pp. 629-648.

Ponnert, L. \& Svensson, Kerstin (2008). Att starta ett program. Första stegen i arbetet med SiSKomet. SiS följer upp och utvecklar 4/08. Stockholm: Statens institutionsstyrelse.

Prop. 2007/08:110 En förnyad folkhälsopolitik. Socialdepartementet.

Sahlin-Andersson, K. (1996). Imitating by Editing Success: The Construction of Organizational Fields. I Czarniawska, B.\& Sevón, G. (red.) Translating Organizational Change. Berlin: de Gruyter.

Sallnäs, M.(2006). Institutionsvård av barn och ungdomar. I Denvall V.\& Vinnerljung B. (red.) Nytta och Fördärv. Socialt arbete i kritisk belysning. Stockholm: Natur och Kultur.

SBU, Statens beredning för medicinsk utvärdering (2010). Program för att förebygga psykisk ohälsa hos barn. En systematisk litteraturöversikt. SBU: Stockholm.

Socialstyrelsen (2004). Lägesrapport, individ- och familjeomsorg. Stockholm.

Socialstyrelsen (2006). Öppenvairdens former. En nationell kartläggning av öppna insatser $i$ socialtjänstens barn- och ungdomsvård. Stockholm.

SOU 2008:131 Föräldrastöd - en vinst för alla. Nationell strategi för samhällets stöd och hjälp till föräldrar i deras föräldraskap. Socialdepartementet \& Föräldrastödsutredningen.

Statens Institutionsstyrelse (2011). MulitfunC. Multifunktionell behandling på institution och $i$ närmiliö. Webbdokument. Tillgängligt: http:// www.stat-inst.se/Documents/projekt/multifunc/multifunc-multifunktionell-behandlingpa-institution-och-i-narmiljo.pdf (110610)

Thompson, J. D. (1971). Hur organisationer fungerar.Prisma: Stockholm. 


\section{Summary}

\section{When packed ideas confront organizational conditions}

This article gives an example of what happens when a programme based on a standardized manual is implemented in a human service organization. Manual-based programmes have been highly idealized in the last decade, since standardized procedures facilitate evaluation, and correspond to the idea of evidence-based practice. The article consists of an analysis of the first part of a research project designed to evaluate the implementation process of a parent-management-training programme called "Komet" in a couple of homes for special supervision in Sweden during 2007-2008. These homes are state institutions for teenagers displaying severe antisocial behaviour. Komet was initially designed for parents with small children and has not previously been used in institutional care. The material consists of interviews with the three educators of the programme, questionnaires distributed to personnel who received training in 2007-2008 and three group interviews with personnel from different homes for special supervision.

We use concepts from neo-institutional theory to analyse the implementation process. Our empirical findings suggest that the implementation of new interventions in human service organizations should be understood as a process of translation, where various factors such as the programme (as an artefact), personnel in the organization, and claims and institutionalized ideas from the organizational field contribute to incorporating a programme in an organizational context. These forces can be so powerful that a programme may be incorporated and kept in an organization despite an awareness of the restricted capacity of the organization to run the programme. In our empirical example an intervention designed for non-institutional care was incorporated in institutional care. A major conclusion is that treatment programmes based on written manuals are grounded in the idea of diffusion, since fidelity to the standardized manual is essential, which is based on a defective organizational understanding of how organizations "think". 